Original Article

\title{
Pellitorine, an extract of Tetradium daniellii, is an antagonist of the ion channel TRPV1
}

\author{
Zoltán Oláh ${ }^{\mathrm{a}, \mathrm{b}, 1}$, Dóra Rédei ${ }^{\mathrm{c}}$, László Pecze ${ }^{\mathrm{a}, 2}$, Csaba Vizler ${ }^{\mathrm{d}}$, Katalin Jósvay ${ }^{\mathrm{a}, \mathrm{d}}$, Péter Forgóc \\ Zoltán Winter $^{a, 3}$, György Dombi ${ }^{a}$, Gerda Szakonyi ${ }^{a, *}$, Judit Hohmann ${ }^{\text {,e }}$ \\ a Institute of Pharmaceutical Analysis, Faculty of Pharmacy, University of Szeged, Szeged, Hungary \\ ${ }^{\mathrm{b}}$ Acheuron Hungary Ltd., Szeged, Hungary \\ ${ }^{c}$ Department of Pharmacognosy, University of Szeged, Szeged, Hungary \\ d Institute of Biochemistry, Biological Research Centre of the Hungarian Academy of Sciences, Szeged, Hungary \\ e Interdisciplinary Centre of Natural Products, University of Szeged, Eötvös u. 6., H-6720 Szeged, Hungary
}

\section{A R T I C L E I N F O}

\section{Keywords:}

TRP channels

Pain

Calcium transport

Pellitorine

Tetradium daniellii

\begin{abstract}
A B S T R A C T
Background: Transient Receptor Potential Vanilloid 1 (TRPV1) confers noxious heat and inflammatory pain signals in the peripheral nervous system. Clinical trial of resiniferatoxin from Euphorbia species is successfully aimed at TRPV1 in cancer pain management and heading toward new selective painkiller status that further validates this target for drug discovery efforts. Evodia species, used in traditional medicine for hundreds of years, are a recognised source of different TRPV1 agonists, but no antagonist has yet been reported.

Hypothesis/Purpose: In a search for painkiller leads, we noted for the first time a TRPV1 antagonist activity in the fresh fruits of Tetradium daniellii (Benn.) T.G. Hartley (syn. Evodia hupehensis Dode).

Methods: Through a combination of extraction and purification methods with functional TRPV1-specific Ca ${ }^{2+}$ uptake assays (bioactivity-guided fractionation/isolation/purification); we isolated a new painkiller candidate that is a distant structural homologue of capsiate exovanilloids and endovanilloids such as anandamide, but a putative competitive inhibitor of the TRPV1. Four additional inactive compounds ( $N$-isobutyl-4,5-epoxy-2Edecadienamide, geranylpsoralen, 8-(7',8'-epoxygeranyloxy)psoralen, and xanthotoxol) were also co-purified with pellitorine. Their structures were established by extensive 1D- and 2D-NMR spectroscopic analysis.

Results: ${ }^{1} \mathrm{H}$ - and ${ }^{13} \mathrm{C}$ NMR determination of the chemical structure revealed it to be pellitorine, $(2 E, 4 E)-N-(2-$ methylpropyl)deca-2,4-dienamide, which can compete structurally with algesics released in inflammation. In contrast to previous isolates from Evodia species, pellitorine blocked capsaicin-evoked $\mathrm{Ca}^{2+}$ uptake with an $\mathrm{IC}_{50}$ of $154 \mu \mathrm{g} / \mathrm{ml}(0.69 \mathrm{mM} / \mathrm{l}) . \quad N$-Isobutyl-4,5-epoxy-2E-decadienamide and geranylpsoralen, 8-(7',8'-epoxygeranyloxy)psoralen, and xanthotoxol did not affect the TRPV1.

Conclusion: This is the first evidence that pellitorine, an aliphatic alkylamide analogue of capsaicin, can serve as an antagonist of the TRPV1 and may inhibit exovanilloid-induced pain.
\end{abstract}

\section{Introduction}

Transient Receptor Potential Vanilloid 1 (TRPV1), one of 28 members of the transient receptor potential (TRP) family of ion channels, transduces pain signals in the peripheral nervous system (PNS) of mammals, including human. TRPV1 expressing nerve endings of C- and
A $\delta$-type primary afferent nociceptive neurons are triggered by endo-, and exovanilloids, moderate heat (Tominaga et al., 1998), and acute or chronic inflammatory mediators, either lipid-like eicosanoids (Olah et al., 2001; Zygmunt et al., 1999; Hwang et al., 2000) or sensitized by peptides such as bradykinin (Pan and Chen, 2004; Di Marzo et al., 2002). Moreover, metabolic changes leading to tissue

\footnotetext{
Abbreviations: ANA, anandamide; CAPS, capsaicin; CapZ, capsazepine; HaCaT, human immortalized keratinocyte cell line; pMTH, plasmid containing metallothionein promoter; PNS,

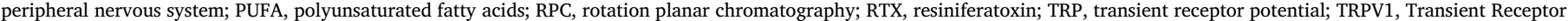
Potential Vanilloid 1

" Corresponding author.

E-mail address: gerda.szakonyi@pharm.u-szeged.hu (G. Szakonyi).

${ }^{1}$ Present address: Institute of Chemistry, Faculty of Material Science and Engineering, University of Miskolc, H-3515, Hungary

${ }^{2}$ Present address: Department of Medicine, University of Fribourg, Fribourg, Switzerland

${ }^{3}$ Present address: Department of Anaesthesiology, Friedrich-Alexander University Erlangen-Nuremberg, Erlangen, Germany
} 
acidification potentiate the receptor for chronic pain signalling (Caterina et al., 1997; Tominaga et al., 1998).

Pain sensation can be reduced by the inhibition of TRPV1, and therefore identification of potent TRPV1 antagonists have been in the focus of research studies. Capsazepine, the first TRPV1 antagonist, was reported by Bevan et al. (1992). Since the identification of TRPV1, numerous TRPV1 antagonists have been synthetized. An efficient antagonist like SB-705,498 (Gunthorpe et al., 2007) showing IC $_{50}$ values at nanomolar range has been demonstrated to block the activation of TRPV1 by capsaicin, heat, and decreased $\mathrm{pH}$. However, potent antagonists of TRPV1 have exhibited undesirable chemical, pharmacological or pharmacokinetic properties such as poor solubility causing decreased absorption (Stec et al., 2008), short half-life (Tafesse et al., 2004), severe hyperthermia (Gavva et al., 2008; Tamayo et al., 2008) or low oral bioavailability (Tafesse et al., 2004). The most effective antagonists such as SB-705498, NEO6860 or JNJ-39439335 have been investigated in clinical trials to evaluate their safety and efficacy in the treatment of various pain-associated conditions. Phase I and II studies of the above mentioned compounds have been completed without publication of results or terminated because of insufficient number of study subjects.

It is perhaps not surprising that number of plant species have evolved secondary metabolites, which target the TRPV1 in mammals to defend themselves. Thus, RTX and analogous irritant vanilloid phytotoxins most likely have evolved to repel herbivorous mammals. From the Evodia genus evodiamine and rutaecarpine have been described as moderate agonists of the TRPV1 (Pearce et al., 2004; Deng and Li, 2005; Wang et al., 2005; Yi et al., 2004; Yu et al., 2005). However, there has as yet no report of any antagonist which may inhibit pain through competition with bona fide endovanilloids at binding site of the TRPV1. We have therefore investigated Tetradium. daniellii in a search for new vanilloid analogues targeting the TRPV1 either as agonists or antagonists.

\section{Materials and methods}

For vacuum liquid chromatography (VLC) TLC silica gel $60 \mathrm{G} 15 \mu \mathrm{m}$ (Merck, Darmstadt, Germany) was used. For open column chromatography (OCC) LiChroprep RP-18 (40-63 $\mu \mathrm{m}$, Merck, Darmstadt, Germany) was applied. Preparative TLC was carried out on $20 \times 20 \mathrm{~cm}$ silica gel (Silica gel $60 \mathrm{~F}_{254}$, Merck, Darmstadt, Germany) plates. Rotation planar chromatography (RPC) was performed using Chromatotron (Model 8924, Harrison Research, Palo Alto, CA, USA) on manually prepared silica gel layer, thickness $2 \mathrm{~mm}$ (Silica gel $60 \mathrm{GF}_{254}$, Merck, Darmstadt, Germany). Chromatographic fractions were monitored by TLC on silica gel (Merck 5715), visualized by spraying with conc. $\mathrm{H}_{2} \mathrm{SO}_{4}$, followed by heating. NMR spectra were recorded in $\mathrm{CDCl}_{3}$ on a Bruker Avance DRX 500 spectrometer at $500 \mathrm{MHz}\left({ }^{1} \mathrm{H}\right)$ or $125 \mathrm{MHz}$ $\left({ }^{13} \mathrm{C}\right)$; the signals of the deuterated solvent were taken as the reference.

All chemicals and reagents were commercially available. Analytical grade reagents were used during the extraction of plant material. For HPLC separation, high purity solvents for HPLC were used. During in vitro and in vivo assays, tissue culture quality chemicals or solvents were used.

\section{Plant material}

The fruits of $T$. daniellii were collected in a public park at Hódmezővásárhely (Hungary) in September, and were stored at $-15{ }^{\circ} \mathrm{C}$ until preparation. A voucher specimen (No. 760) has been deposited in the Herbarium of the Department of Pharmacognosy, University of Szeged, Szeged, Hungary.

\section{Extraction and isolation}

The frozen plant material $(10 \mathrm{~kg})$ was percolated with $\mathrm{MeOH}(60 \mathrm{l})$ at room temperature. After concentration to $1.5 \mathrm{l}$, the $\mathrm{MeOH}$ extract was partitioned between cyclohexane $(4 \times 1.51), \mathrm{CHCl}_{3}(4 \times 1.5 \mathrm{l})$ and $\mathrm{H}_{2} \mathrm{O}$. The cyclohexane layer was dried in vacuum yielding a dark green oily residue $(110 \mathrm{~g})$, which was subjected to VLC (VLC-1) on silica gel, using a gradient system of cyclohexane - EtOAc - EtOH (100:0:0, 19:1:0, 9:1:0, 4:1:0, 7:3:0, 70:30:3, 15:10:1, and 1:1:1). Altogether 83 fractions, each of $250 \mathrm{ml}$, were collected and successively combined in 18 fractions (Evo1 - Evo18) after TLC monitoring. Combined fractions Evo10, eluted with cyclohexane - EtOAc - EtOH (4:1) exhibited capsaicin (CAPS)-induced $\mathrm{Ca}^{2+}$-uptake inhibitory activity, and were further fractionated by means of VLC (VLC-2) on silica gel with $n$-hexane acetone mixtures of increasing polarity $(19: 1,9: 1,17: 3,4: 1,3: 1,7: 3$, and 3:2). The fractions obtained here were combined in nine main fractions (Evo10/1 - Evo10/9) depending on their compositions. Only one fraction (Evo10/1) was found to be effective, and was re-chromatographed by OCC on RP-18 silica gel with elution of 70, 75, 80, 85, 90, 95 and 100\% $\mathrm{MeOH}$. The combined fractions (Evo10/1/A - Evo10/1/ $\mathrm{H})$ from this separation were assayed for their efficacy, and the active fraction Evo10/1/B was selected for further chromatography. This fraction was purified by preparative TLC on silica gel using $\mathrm{CHCl}_{3}-$ acetone (49:1) as developing system, to afford pellitorine (1) $(2.4 \mathrm{mg})$ (Fig. 4). after three-step chromatographic separations using VLC (silica gel, $n$-hexane - acetone gradient), RPC (silica gel, toluene - ethyl acetate gradient) and preparative TLC (silica gel, $\mathrm{CHCl}_{3}$ - acetone 19:1), combined fractions 29-33 from the VLC-1 separation yielded $\mathrm{N}$-isobutyl-4,5-epoxy-2E-decaenamide (3) $(1.2 \mathrm{mg}), 8$-geranyloxypsoralen (5) (150 mg), 8-(7', $8^{\prime}$-epoxygeranyloxy)psoralen (7) (2.3 mg) and xanthotoxol (4) (4.3 mg) (Fig. 4).

(2E,4E)- $N$-(2-methylpropyl)deca-2,4-dienamide (=pellitorine) (1): amorphous solid; ${ }^{1} \mathrm{H}$ NMR ( $\left.500 \mathrm{MHz}, \mathrm{CDCl}_{3}, \delta \mathrm{ppm}\right): 5.74(1 \mathrm{H}, \mathrm{d}$, $J=15.0 \mathrm{~Hz}, \mathrm{H}-2), 7.18(1 \mathrm{H}, \mathrm{dd}, J=15.0,10.2 \mathrm{~Hz}, \mathrm{H}-3), 6.12(1 \mathrm{H}, \mathrm{dd}$, $J=15.2,10.4 \mathrm{~Hz}, \mathrm{H}-4), 6.07$ (1H, dt, $J=15.1,6.4 \mathrm{~Hz}, \mathrm{H}-5), 2.13(2 \mathrm{H}$, dt, $J=7.2,6.9 \mathrm{~Hz}, \mathrm{H}-6), 1.39$ (2H, m, H-7), 1,32 - 1,2 (4H, m, H-8, H9), 0.87 (3H, t, $J=7.0 \mathrm{~Hz}, \mathrm{H}-10$ ), $3.15\left(1 \mathrm{H}, \mathrm{t}, J=6.5 \mathrm{~Hz}, \mathrm{H}-1^{\prime}\right), 1.79$ (1H, sept, $\left.J=6.7 \mathrm{~Hz}, \mathrm{H}-2^{\prime}\right), 0.92\left(6 \mathrm{H}, \mathrm{d}, J=6.7 \mathrm{~Hz}, \mathrm{H}-3^{\prime}, 4^{\prime}\right), 5.49(1 \mathrm{H}$, brs, NH). The data are identical with those published by Ley et al. (2004).

$N$-isobutyl-4,5-epoxy-2E-decaenamide (2): amorphous solid; ${ }^{1} \mathrm{H}$ NMR (500 MHz, $\left.\mathrm{CDCl}_{3}, \delta \mathrm{ppm}\right): 6.06(1 \mathrm{H}, \mathrm{d}, J=15.2 \mathrm{~Hz}, \mathrm{H}-2), 6.65$ (1H, dd, $J=15.2,6.4 \mathrm{~Hz}, \mathrm{H}-3), 3.19$ (1H, brd, $J=6.4 \mathrm{~Hz}, \mathrm{H}-4), 2.85$ (1H, dt, $J=6.4,1.9 \mathrm{~Hz}, \mathrm{H}-5), 1.60$ (2H, m, H-6), 1.43 (2H, m, H-7), $1.32(4 \mathrm{H}, \mathrm{m}, \mathrm{H}-8, \mathrm{H}-9), 0.90(3 \mathrm{H}, \mathrm{t}, J=7.3 \mathrm{~Hz}, \mathrm{H}-10), 3.16(1 \mathrm{H}, \mathrm{t}$, $\left.J=6.5 \mathrm{~Hz}, \mathrm{H}-1^{\prime}\right), 1.80\left(1 \mathrm{H}\right.$, sept, $\left.J=6.7 \mathrm{~Hz}, \mathrm{H}-2^{\prime}\right), 0.93(6 \mathrm{H}, \mathrm{d}$, $\left.J=6.7 \mathrm{~Hz}, \mathrm{H}-3^{\prime}, 4^{\prime}\right), 5.5(1 \mathrm{H}$, brs, NH). The data are in good agreement with those published by Wei et al. (2004).

8-Geranyloxypsoralen (3): white crystals; mp. $57-59{ }^{\circ} \mathrm{C} ;{ }^{1} \mathrm{H}$ NMR $\left(500 \mathrm{MHz}, \mathrm{CDCl}_{3}, \delta \mathrm{ppm}\right): 6.35(1 \mathrm{H}, \mathrm{d}, J=9.6 \mathrm{~Hz}, \mathrm{H}-3), 7.75(1 \mathrm{H}, \mathrm{d}$, $J=9.6 \mathrm{~Hz}, \mathrm{H}-4), 7.35$ (1H, s, H-5), $6.80(1 \mathrm{H}, \mathrm{d}, J=2.1 \mathrm{~Hz}, \mathrm{H}-6), 7.68$ $(1 \mathrm{H}, \mathrm{d}, J=2.1 \mathrm{~Hz}, \mathrm{H}-7), 5.01$ (3H, m, H-1', H-7'), $5.59(2 \mathrm{H}, \mathrm{t}$, $\left.J=7.0 \mathrm{~Hz}, \mathrm{H}-2^{\prime}\right), 1.69$ (3H, s, H-4'), 2.00 (4H, m, H-5', H-6'), 1.56 (3H, s, H-9'), 1.64 (3H, s, H-10'); ${ }^{13} \mathrm{C}$ NMR (125 MHz, $\mathrm{CDCl}_{3}, \delta$ ppm): 160.5 (C-2), 114.7 (C-3), 144.3 (C-4), 113.2 (C-5), 106.7 (C-6), 146.6 (C-7), 143.1 (C-8), 144.0 (C-9), 116.5 (C-10), 125.8 (C-11), 149.0 (C-12), 70.1 (C-1'), 119.4 (C-2'), 131.6 (C-3'), 16.5 (C-4'), 39.6 (C-5'), 26.3 (C-6'), 123.8 (C-7'), 131.7 (C-8'), 17.6 (C-9'), 25.6 (C-10'). NMR chemical shifts are in good agreement with the published values (Miyake et al., 1999).

8-(7', $8^{\prime}$-Epoxygeranyloxy)psoralen (4): amorphous solid; ${ }^{1} \mathrm{H}$ NMR $\left(500 \mathrm{MHz}, \mathrm{CDCl}_{3}, \delta \mathrm{ppm}\right): 6.37(1 \mathrm{H}, \mathrm{d}, J=9.6 \mathrm{~Hz}, \mathrm{H}-3), 7.76(1 \mathrm{H}, \mathrm{d}$, $J=9.6 \mathrm{~Hz}, \mathrm{H}-4), 7.36(1 \mathrm{H}, \mathrm{s}, \mathrm{H}-5), 6.81(1 \mathrm{H}, \mathrm{d}, J=2.1 \mathrm{~Hz}, \mathrm{H}-6), 7.69$ $(1 \mathrm{H}, \mathrm{d}, J=2.1 \mathrm{~Hz}, \mathrm{H}-7), 5.03\left(2 \mathrm{H}, \mathrm{d}, J=7.1 \mathrm{~Hz}, \mathrm{H}-1^{\prime}\right), 5.65(2 \mathrm{H}, \mathrm{t}$, $\left.\mathrm{J}=7.1 \mathrm{~Hz}, \mathrm{H}-2^{\prime}\right), 1.73$ (3H, s, H-4'), 2.17 (1H, m, H-5'), $2.14(1 \mathrm{H}, \mathrm{m}, \mathrm{H}-$ $\left.5^{\prime}\right), 1.59\left(2 \mathrm{H}, \mathrm{m}, \mathrm{H}-6^{\prime}\right), 2.64 \mathrm{t}\left(1 \mathrm{H}, J=6.2 \mathrm{~Hz}, \mathrm{H}-7^{\prime}\right), 1.24$ (3H, s, H-9'), $1.28\left(3 \mathrm{H}, \mathrm{s}, \mathrm{H}-10^{\prime}\right)$. The data are in good agreement with those published by Ziegler and Spiteller (1992).

Xanthotoxol (5): white crystal; mp. $249-250^{\circ} \mathrm{C}$. Identification of 5 
was on the basis of its TLC co-elution with authentic standard and on its ${ }^{1}$ H NMR spectrum (Harkar et al., 1984).

CAPS and capsazepine (CapZ), a well characterized antagonist of TRPV1, were dissolved in DMSO (all from Sigma, St. Louis, MO, USA). RTX (LC Laboratories, Woburn, MA, USA) was dissolved in ethanol at $2 \mathrm{mg} / \mathrm{ml}$ concentration and further diluted in $\mathrm{ddH}_{2} \mathrm{O}$.

\section{Cell culture and preparation of permanent TRPV1-HaCaT cell line}

The spontaneously immortalized human keratinocyte cell line HaCaT was kindly provided by Dr. Fusenig, Heidelberg, Germany (Boukamp et al., 1988), and cultured in MIXMEM medium supplemented with $10 \%$ FCS (Sigma-Aldrich, St. Louis, MO, USA).

The C-terminally tagged rat TRPV1 $\varepsilon$ DNA (accession number: NM_031982.1) construct was prepared in the plasmid vector containing metallothionein promoter (pMTH) as described previously (Olah et al., 2001). To avoid the decrease in cell survival that occurs when the TRPV1 is overexpressed, only the basal activity of the inducible metallothionein promoter was used. To prepare a cell line permanently expressing the TRPV1, HaCaT cells were transfected with the plasmid vector using the Exgen 500 reagent according to the recommendations of the manufacturer. After $24 \mathrm{~h}$ cells were transferred to selection medium, containing $0.8 \mathrm{mg} / \mathrm{ml} \mathrm{G} 418$ (Sigma, St. Louis, MO, USA) which was replaced every second day. After about a month, G418-resistant colonies were tested with vanilloid-induced ${ }^{45} \mathrm{Ca}^{2+}$ uptake assays and a colony exhibiting 20 -fold above the base line uptake was chosen for further studies.

${ }^{45} \mathrm{Ca}^{2+}$ uptake assay

One day before the assay, cells were seeded in 96-well flat bottom plates (Orange Scientific, Braine-l'Alleud, Belgium) at a density of 20,000 cells/well and left for duplication O/N. The assays were performed with a BioMek 1000 robotized liquid handler (Beckman Instruments Inc., Fullerton, CA, USA). The plates were washed three times with assay medium $\left(\mathrm{Ca}^{2+}\right.$ - and $\mathrm{Mg}^{2+}$-free Hanks' balanced salt solution supplemented $0.8 \mathrm{mM} \mathrm{MgCl}_{2}$ and with $25 \mathrm{mM}$ Tris- $\mathrm{HCl}$, $\mathrm{pH}=7.4$ ). CAPS dilutions in the presence of ${ }^{45} \mathrm{Ca}^{2+}$ were prepared by the robot. The $\mathrm{Ca}^{2+}$ uptake assay was performed for $10 \mathrm{~min}$ at $24^{\circ} \mathrm{C}$ using $0.07 \mu \mathrm{Ci}$ of ${ }^{45} \mathrm{Ca}^{2+}$ in $100 \mu \mathrm{l}$ final volume/well. To terminate ${ }^{45} \mathrm{Ca}^{2+}$ uptake and remove the free isotope, cells were washed three additional times and then lysed in $100 \mu \mathrm{l} /$ well lysis buffer ( $50 \mathrm{mM}$ Tris$\mathrm{HCl}, \mathrm{pH} 7.5,150 \mathrm{mM} \mathrm{NaCl}, 1 \%$ Triton X-100, 0.1\% SDS, 5 mM EDTA) for $30 \mathrm{~min}$. Eighty $\mu \mathrm{l}$ aliquots of the solubilized cell extracts were mixed with $120 \mu \mathrm{l}$ aliquots of Optiphase Supermix scintillation cocktail (Perkin Elmer, Wellesley, MA, USA) and counted in a Perkin Elmer liquid scintillation counter.

\section{Eye wipe test}

Hundred $\mu \mathrm{M}$ of CAPS solution in $0.05 \%$ of methylcellulose or $100 \mu \mathrm{M}$ of CAPS solution supplemented with $3.75 \mathrm{mM}$ of pellitorine in $0.05 \%$ of methylcellulose was dropped into the eyes of the BALB/c mice and the number of defensive wiping movements was counted for $2 \mathrm{~min}$. Two-tailed $t$-test was used for statistical analysis. The group number was 7 or higher.

\section{Results and discussion}

The extraction and the purification of cyclohexane phase of fruits of Tetradium daniellii (Benn.) T.G. Hartley (syn. Evodia hupehensis Dode) resulted in the isolation of five compounds. The concentrated $\mathrm{MeOH}$ extracts were partitioned between cyclohexane, $\mathrm{CHCl}_{3}$ and $\mathrm{H}_{2} \mathrm{O}$. VLC separation of the active component containing cyclohexane fraction (Fig. 1A) on silica gel, using a gradient system of cyclohexane/EtOAc/ $\mathrm{EtOH}$, resulted 18 fractions with different composition (Evo1 - Evo18).
Fraction Evo10 exhibited antagonist activity on CAPS-induced ${ }^{45} \mathrm{Ca}^{2+}$ uptake in the TRPV1-HaCaT keratinocyte cell line (Fig. 1B). To test the antagonist activity of the extracts, the TRPV1-HaCaT cells were activated for maximal ${ }^{45} \mathrm{Ca}^{2+}$ uptake with $2 \mu \mathrm{M}$ CAPS, a sub-maximum dose that was stringent enough, but did not cause cell damage due to $\mathrm{Ca}^{2+}$-excitotoxicity. Fractions to be tested were then co-incubated for 10 min with a ${ }^{45} \mathrm{Ca}^{2+}$ uptake solution, and the accumulation of the radioactive tracer in the adhesive TRPV1-HaCaT cell line was determined. For agonist activity tests, increasing concentrations of the extracts were used instead of CAPS in the same assay. Pellitorin had no effect on the $\mathrm{Ca}^{2+}$ uptake of the non-transfected HaCaT cell line that does not express a functional TRPV1 (data is not shown).

In contrast with expectations from previous studies, our extraction procedure from $T$. daniellii fruits revealed potent antagonist activity. The dose-response curves generated with the fraction Evo10 demonstrated full antagonist effect on the TRPV1 (Fig. 1B) with an efficacy of $\mathrm{IC}_{50}=215 \mu \mathrm{g} / \mathrm{ml}$. CapZ, a bona fide inhibitor of the TRPV1 compared side-by-side in a 96 well plate assay (Fig. 1B), gave an $\mathrm{IC}_{50}=5.3 \mu \mathrm{g} / \mathrm{ml}$ showing an only 40 times greater potency of inhibition than that of the crude, but biologically active fraction Evo10.

A VLC procedure with the active fraction Evo10 resulted in the separation of a set of apolar compounds. The fraction Evo10/1 preserved the antagonist activity, the TRPV1-HaCaT cell-based bioassay resulting in $\mathrm{IC}_{50}=57 \mu \mathrm{g} / \mathrm{ml}$ (Fig. 1C).

To attain complete homogeneity, fraction Evo10/1 was subjected to OCC on the RP-18 stationary phase. This led to the separation of eight fractions (Evo10/1A - Evo10/1H) of which Evo10/1B was the most effective as concerns CAPS-induced $\mathrm{Ca}^{2+}$ uptake $\left(\mathrm{IC}_{50}=32 \mu \mathrm{g} / \mathrm{ml}\right.$ ), determined with the TRPV1-HaCaT cell line (Fig. 1D).

The final step of Evo10/1B purification by preparative TLC yielded a pure compound. Structure analysis identified this TRPV1 inhibitor as pellitorine (1). As a structural analogue of CAPS (2), it inhibited TRPV1 in a concentration-dependent manner with $\mathrm{IC}_{50}=154 \mu \mathrm{g} / \mathrm{ml}$ $(0.69 \mathrm{mM} / \mathrm{l})$ (Fig. 2). The higher $\mathrm{IC}_{50}$ value of pellitorine compared that of the Evo10/1B fraction might be caused by the potential loss of other active components during the purification procedure.

The extensive purification procedures yielded fractions containing other compounds that were purified either completely or nearly to homogeneity; these were determined by ${ }^{1} \mathrm{H}$ NMR spectrometry as: $N$ isobutyl-4,5-epoxy-2E-decaenamide (3), one of the closest, though surprisingly, completely inactive epoxy-derivatives of pellitorine; and several coumarins such as 8-geranyloxypsoralen (5), 8-(7', $8^{\prime}$-epoxygeranyloxy)psoralen (7) and xanthotoxol (4), were also co-purified (Fig. 4). None of these distant, xanthotoxol-derivatised homologues were proved active in the functional TRPV1 bioassay. On the contrary, a previous study investigated imperatorin, a furocoumarin that showed weak agonist activity on TRPV1 (Chen et al., 2014).

Following in vitro tests, pellitorine was challenged in vivo tests of eye wiping in response to pungent vanilloids. $3.75 \mathrm{mM}$ pellitorine applied together with $100 \mu \mathrm{M}$ CAPS significantly $(\mathrm{p}=0016)$ decreased the frequency of vanilloid-evoked defending movements (Fig. 3). The number of eye wiping movements evoked by $100 \mu \mathrm{M}$ CAPS, however, did not change significantly following either a $1 \mathrm{~h}$ or $15 \mathrm{~min}$ pretreatment with $3.75 \mathrm{mM}$ or $4.5 \mathrm{mM}$ pellitorine. Consequently, pellitorine inhibited the pain-evoked defensive movements of BALB/c mice in response to pungent vanilloids.

To date, only TRPV1 agonists have been described from extracts of Evodia species, compounds that are also known to induce the release of inflammatory CGRP and substance P, both of them peptide agonists of CGRP receptors and neurokinin receptors, respectively, and are involved in the transmission of pain signals in second-order neurons of the PNS (Kobayashi et al., 2001). However, in our research study the cyclohexane-soluble phase was found to inhibit CAPS-induced $\mathrm{Ca}^{2+}$. uptake in either HaCaT keratinocytes from human or NIH3T3 mouse fibroblasts (results not shown) expressing TRPV1 ectopically.

The "inflammatory soup" is rich in potent endogenous agonists of 
A
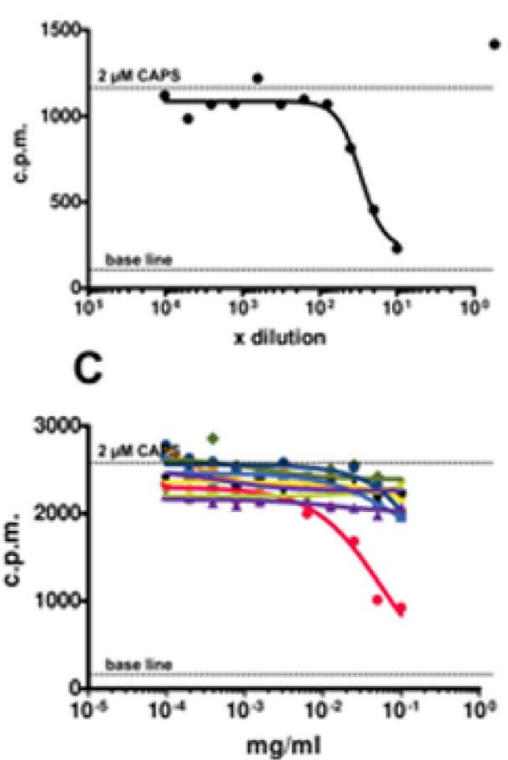

B

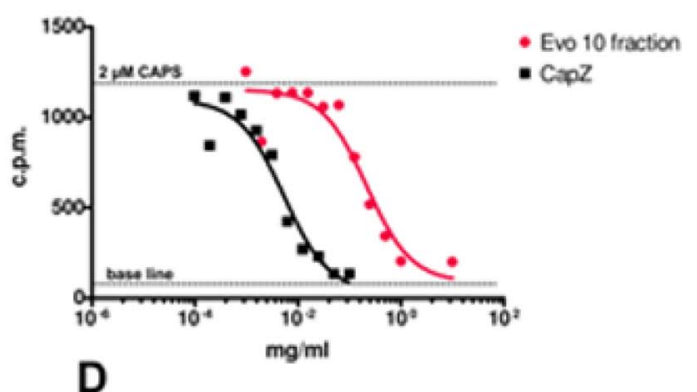

D

- Evo 10/1

- Evo 10/2

Evo 10/3

- Evo 10/4

- Evo 10/5

- Evo $10 / 6$

- Evo 10/7

* Evo 10/8

- Evo $10 / 9$

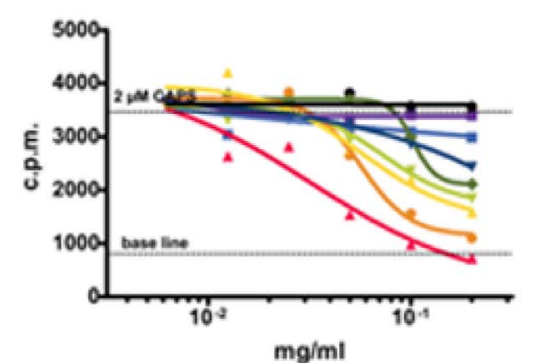

- $\mathrm{EtOH}$

= Evo 10/1 A

$\triangle$ Evo 10/1 B

* Evo 10/1 C

- Evo 10/1 E

- Evo 10/1 F

- Evo 10/1 G

Evo 10/1 H

- Evo 10/1

Fig. 1. The effect of fractions from Tetradium daniellii fruits on the TRPV1

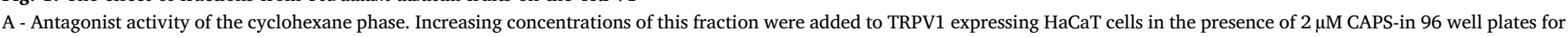

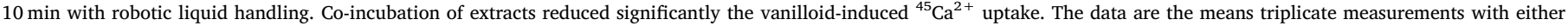
TRPV1-HaCaT or TRPV1-NIH3T3 permanent cell lines.

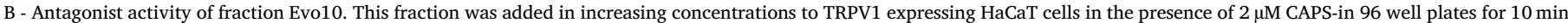

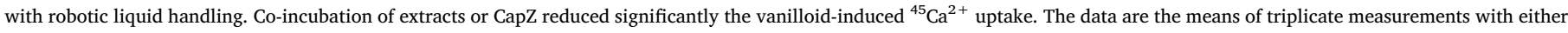
TRPV1-HaCaT or TRPV1-NIH3T3 permanent cell lines.

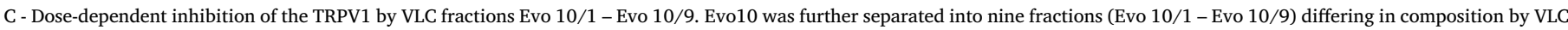

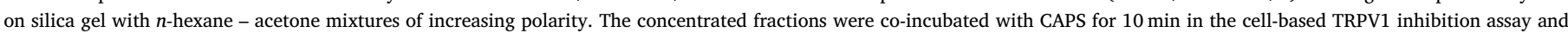

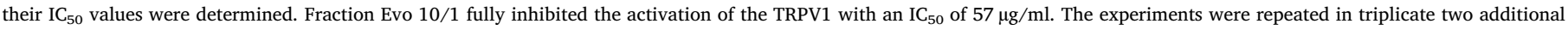
times with similar results.

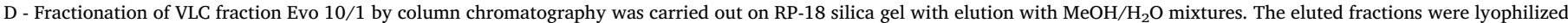

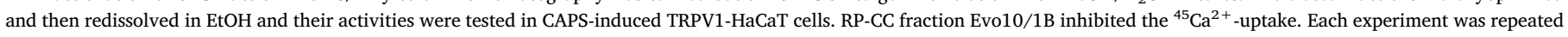
in triplicate at least two additional times with similar results.

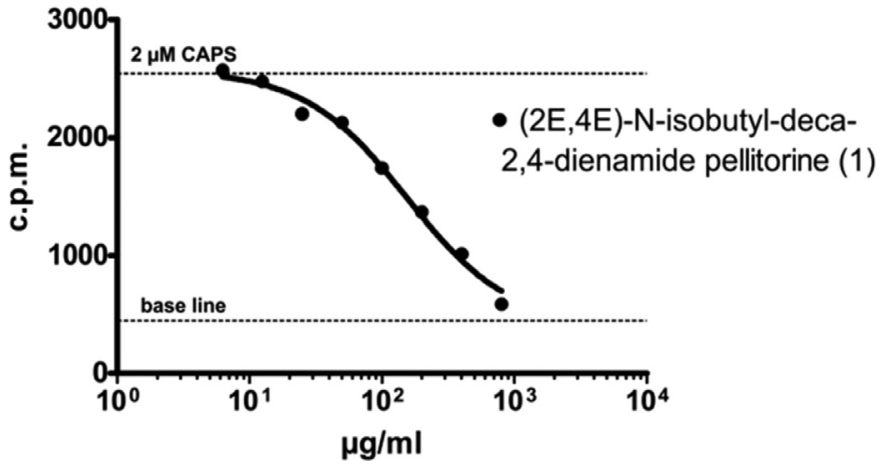

Fig. 2. Profiling of inhibitory activity of pellitorine (1). The membrane transport of ${ }^{45} \mathrm{Ca}^{2+}$ was characterized in the presence of progressively increasing concentrations of pellitorine. Kinetics similar to that represented here was observed in two additional experiments, carried out in duplicate samples.

TRPV1, such as (but not confined to) eicosanoids and prostaglandin analogues. Anandamide, 15-(S)-hydroperoxyeicosatetraenoic acid (6), 5-, and 15-(S)-hydroxyeicosatetraenoic acids, leukotriene $\mathrm{B}(4), \mathrm{N}$ oleoyldopamine, and $N$-oleoylethanolamine (8) are the best-known endogenous algesics in inflammation (Chu et al., 2003; Olah et al., 2001; Hwang et al., 2000). Similarly to skin-irritating phorbol esters, certain polyunsaturated fatty acids (PUFAs), such as omega-3, have been demonstrated to upregulate the TRPV1 via the protein kinase mediated phosphorylation of Ser502 and Ser800 of TRPV1 (Matta et al., 2007). Moreover, the activation of cyclooxygenase isozymes leads to the generation of numbers of agonists showing structural similarity to
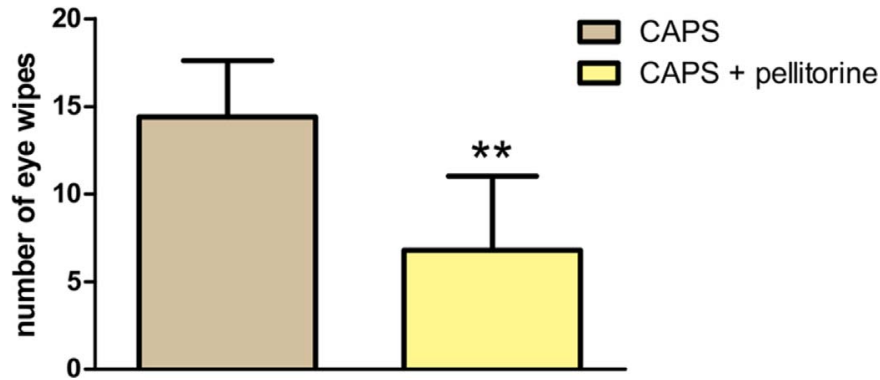

Fig. 3. Effects of pellitorine (1) on the pain sensation of BALB/c mice in eye wipe tests. $3.75 \mathrm{mM}$ pellitorine applied together with $100 \mu \mathrm{M}$ CAPS significantly ( $\mathrm{p}=0.016$, twotailed $t$-test) decreased the frequency of vanilloid-evoked defensive movements. The experiment was performed 3 times, with similar results, group number $\geq 7$.

pellitorine.

Our study has provided the first evidence that pellitorine, an aliphatic alkylamide analogue of CAPS, inhibits TRPV1. Evodia species are recognised sources of bioactive substances, but previous studies indicated only agonist activity on TRPV1 (Beak et al., 2004; Pearce et al., 2004). 8-geranyloxypsoralen (5) and other coumarins, such as $8-\left(7^{\prime}, 8^{\prime}\right.$ epoxygeranyloxy)psoralen (7) and xanthotoxol (4) (Fig. 4), proved inactive in our functional TRPV1 bioassay.

\section{Conclusion}

Pellitorine may also be considered as a structural homologue of exovanilloids, however, it was found to be an antagonist rather than agonist of TRPV1. Pellitorine, one of the natural substances of 


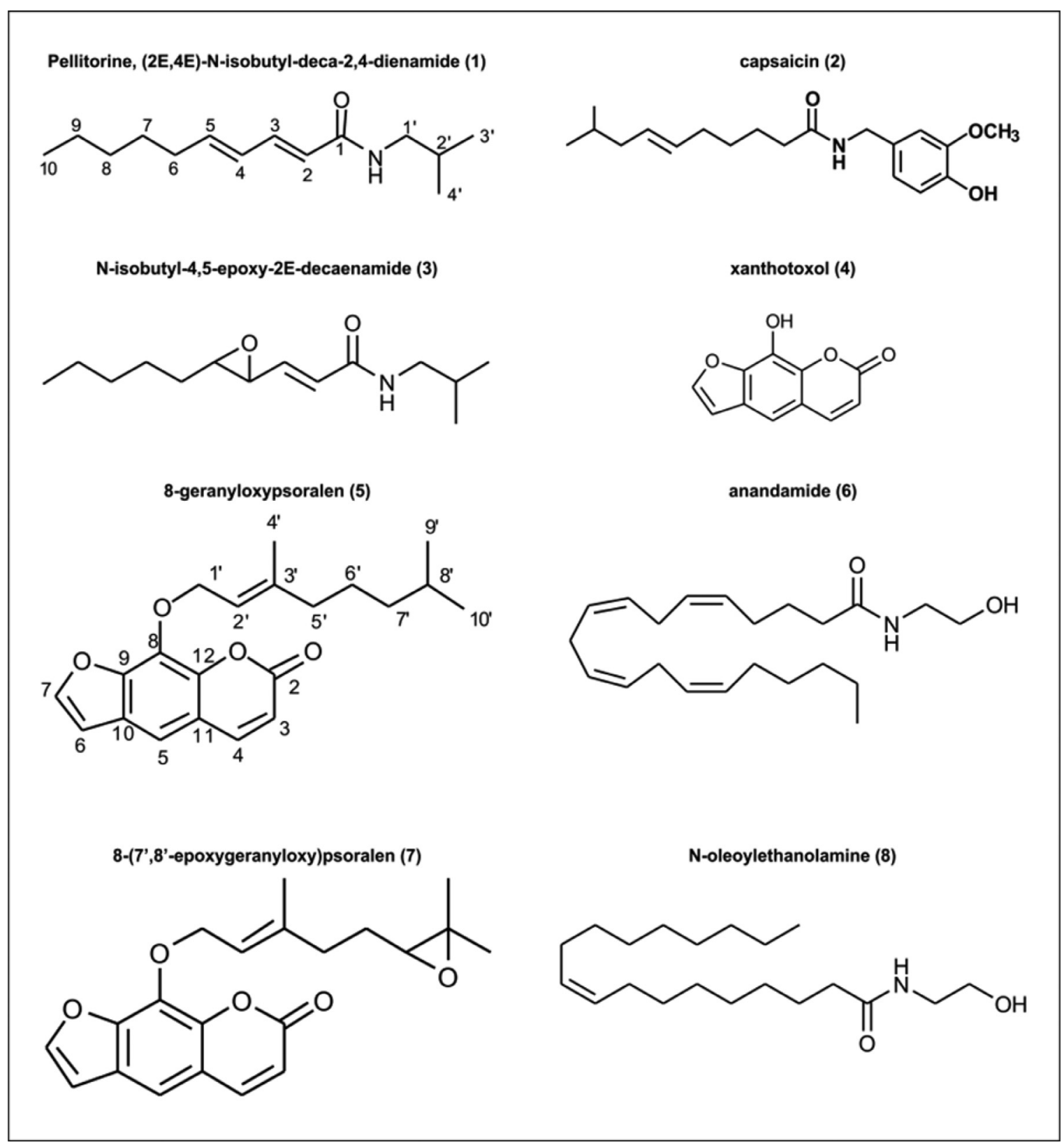

Fig. 4. Structures of compounds mentioned in the text.

Tetradium daniellii, and Piper longum l. (Liu et al., 2015), a new antagonist of TRPV1 showed a completely different chemical structure than that of previously described potent antagonists of TRPV1. Copurified homologous compounds, that are either active or inactive on TRPV1 $\mathrm{Ca}^{2+}$-channel activation, can serve as valuable lead structures in medicinal chemistry in directing these pharmacophores to the therapeutic target with improved specificity and efficacy.

\section{Conflict of interest}

The authors declare no conflict of interest.

\section{Acknowledgments}

ZO was supported by MC-IRG030854-PAINKILLER; GVOP-3.3.1-05/ 1.-2005-05-0057/3.0. CV was supported by grants the National Office for Research and Technology (OM-00051/2005 and OMFB-01575/ 2006) and the Hungarian Ministry of Health (552/2006). Financial support from the Hungarian Scientific Research Fund (OTKA K109846) is gratefully acknowledged. DR is a grantee of the János Bolyai Research Fellowship of the http://dx.doi.org/10.13039/ 501100003825. The authors thank Professor Kálmán Szendrei (Department of Pharmacognosy, University of Szeged) for his inspiration initiating this study.

\section{References}

Beak, S.M., Paek, S.H., Jahng, Y., Lee, Y.S., Kim, J.A., 2004. Inhibition of UVA irradiationmodulated signaling pathways by rutaecarpine, a quinazolinocarboline alkaloid, in human keratinocytes. Eur. J. Pharmacol. 498, 19-25.

Bevan, S., Hothi, S., Hughes, G., James, I.F., Rang, H.P., Shah, K., Walpole, C.S., Yeats, J.C., 1992. Capsazepine: a competitive antagonist of the sensory neurone excitant capsaicin. Br. J. Pharmacol. 107, 544-552.

Boukamp, P., Petrussevska, R.T., Breitkreutz, D., Hornung, J., Markham, A., Fusenig, N.E., 1988. Normal keratinization in a spontaneously immortalized aneuploid human keratinocyte cell line. J. Cell Biol. 106, 761-771.

Caterina, M.J., Schumacher, M.A., Tominaga, M., Rosen, T.A., Levine, J.D., Julius, D., 1997. The capsaicin receptor: a heat-activated ion channel in the pain pathway. Nature 389, 816-824. 
Chen, X., Sun, W., Gianaris, N.G., Riley, A.M., Cummins, T.R., Fehrenbacher, J.C., Obukhov, A.G., 2014. Furanocoumarins are a novel class of modulators for the transient receptor potential vanilloid type 1 (TRPV1) channel. J. Biol. Chem. 289, 9600-9610.

Chu, C.J., Huang, S.M., De Petrocellis, 1., Bisogno, T., Ewing, S.A., Miller, J.D., Zipkin, R.E., Daddario, N., Appendino, G., Di Marzo, V., Walker, J.M., 2003. N-oleoyldopamine, a novel endogenous capsaicin-like lipid that produces hyperalgesia. J. Biol. Chem. 278, 13633-13639.

Deng, P.Y., Li, Y.J., 2005. Calcitonin gene-related peptide and hypertension. Peptides 26, 1676-1685.

Di Marzo, V., Blumberg, P.M., Szallasi, A., 2002. Endovanilloid signaling in pain. Curr. Opin. Neurobiol. 12, 372-379.

Gavva, N.R., Treanor, J.J., Garami, A., Ffang, 1., Surapaneni, S., Akrami, A., Alvarez, F., Bak, A., Darling, M., Gore, A., Jang, G.R., Kesslak, J.P., Ni, 1., Norman, M.H., Palluconi, G., Rose, M.J., Salfi, M., Tan, E., Romanovsky, A.A., Banfield, C., Davar, G., 2008. Pharmacological blockade of the vanilloid receptor TRPV1 elicits marked hyperthermia in humans. Pain 136, 202-210.

Gunthorpe, M.J., Hannan, S.l., Smart, D., Jerman, J.C., Arpino, S., Smith, G.D., Brough, S., Wright, J., Egerton, J., Lappin, S.C., Holland, V.A., Winborn, K., Thompson, M., Rami, H.K., Randall, A., Davis, J.B., 2007. Characterization of SB-705498, a potent and selective vanilloid receptor-1 (VR1/TRPV1) antagonist that inhibits the capsaicin-, acid-, and heat-mediated activation of the receptor. J. Pharmacol. Exp. Ther. 321, 1183-1192.

Harkar, S., Razdan, T., Waight, E., 1984. Steroids, chromone and coumarins from Angelica officinalis. Phytochemistry 23, 419-426.

Hwang, S.W., Cho, H., Kwak, J., Lee, S.Y., Kang, C.J., Jung, J., Cho, S., Min, K.H., Suh, Y.G., Kim, D., Oh, U., 2000. Direct activation of capsaicin receptors by products of lipoxygenases: endogenous capsaicin-like substances. Proc. Natl. Acad. Sci. U. S. A. 97, 6155-6160.

Kobayashi, Y., Hoshikuma, K., Nakano, Y., Yokoo, Y., Kamiya, T., 2001. The positive inotropic and chronotropic effects of evodiamine and rutaecarpine, indoloquinazoline alkaloids isolated from the fruits of Evodia rutaecarpa, on the guinea-pig isolated right atria: possible involvement of vanilloid receptors. Planta Med. 67, 244-248.

Ley, J.P., Hilmer, J.M., Weber, B., Krammer, G., Gatfield, I.1., Bertram, H.J., 2004. Stereoselective Enzymatic Synthesis of cis-Pellitorine, a Taste Active Alkamide Naturally Occurring in Tarragon. Eur. J. Org. Chem. 2004, 5135-5140.

Liu, H.1., Luo, R., Chen, X.Q., Ba, Y.Y., Zheng, 1., Guo, W.W., Wu, X., 2015. Identification and simultaneous quantification of five alkaloids in Piper longum 1. by HPLC-ESI-MS (n) and UFLC-ESI-MS/MS and their application to Piper nigrum l. Food Chem. 177, 191-196.

Matta, J.A., Miyares, R.1., Ahern, G.P., 2007. TRPV1 is a novel target for omega-3 polyunsaturated fatty acids. J. Physiol. 578, 397-411.
Miyake, Y., Murakami, A., Sugiyama, Y., Isobe, M., Koshimizu, K., Ohigashi, H., 1999. Identification of coumarins from lemon fruit (Citrus limon) as inhibitors of in vitro tumor promotion and superoxide and nitric oxide generation. J. Agric. Food Chem. 47, 3151-3157.

Olah, Z., Karai, 1., Iadarola, M.J., 2001. Anandamide activates vanilloid receptor 1 (VR1) at acidic pH in dorsal root ganglia neurons and cells ectopically expressing VR1. J. Biol. Chem. 276, 31163-731170.

Pan, H.l., Chen, S.R., 2004. Sensing tissue ischemia: another new function for capsaicin receptors? Circulation 110, 1826-1831.

Pearce, 1.V., Petukhov, P.A., Szabo, T., Kedei, N., Bizik, F., Kozikowski, A.P., Blumberg, P.M., 2004. Evodiamine functions as an agonist for the vanilloid receptor TRPV1. Org. Biomol. Chem. 2, 2281-6228.

Stec, M.M., Bo, Y.X., Chakrabarti, P.P., Liao, 1.1., Ncube, M., Tamayo, N., Tamir, R., Gavva, N.R., Treanor, J.J.S., Norman, M.H., 2008. Substituted aryl pyrimidines as potent and soluble TRPV1 antagonists. Bioorg. Med. Chem. Lett. 18, 5118-5122.

Tafesse, 1., Sun, Q., Schmid, l., Valenzano, K.J., Rotshteyn, Y., Su, X., Kyle, D.J., 2004 Synthesis and evaluation of pyridazinylpiperazines as vanilloid receptor 1 antagonists. Bioorg. Med. Chem. Lett. 14, 5513-5519.

Tamayo, N., Liao, H.Y., Stec, M.M., Wang, X.H., Chakrabarti, P., Retz, D., Doherty, E.M., Surapaneni, S., Tamir, R., Bannon, A.W., Gavva, N.R., Noman, M.H., 2008. Design and synthesis of peripherally restricted transient receptor potential vanilloid 1 (TRPV1) antagonists. J. Med. Chem. 51, 2744-2757.

Tominaga, M., Caterina, M.J., Malmberg, A.B., Rosen, T.A., Gilbert, H., Skinner, K., Raumann, B.E., Basbaum, A.I., Julius, D., 1998. The cloned capsaicin receptor integrates multiple pain-producing stimuli. Neuron 21, 531-543.

Wang, 1., Hu, C.P., Deng, P.Y., Shen, S.S., Zhu, H.Q., Ding, J.S., Tan, G.S., Li, Y.J., 2005. The protective effects of rutaecarpine on gastric mucosa injury in rats. Planta Med 71 , 416-419.

Wei, K., Li, W., Koike, K., Pei, Y., Chen, Y., Nikaido, T., 2004. New amide alkaloids from the roots of Piper nigrum. J. Nat. Prod. 67, 1005-1009.

Yi, H.H., Rang, W.Q., Deng, P.Y., Hu, C.P., Liu, G.Z., Tan, G.S., Xu, K.P., Li, Y.J., 2004. Protective effects of rutaecarpine in cardiac anaphylactic injury is mediated by CGRP. Planta Med 70, 1135-1139.

Yu, J., Tan, G.S., Deng, P.Y., Xu, K.P., Hu, C.P., Li, Y.J., 2005. Involvement of CGRP in the inhibitory effect of rutaecarpine on vasoconstriction induced by anaphylaxis in guinea pig. Regul. Pept. 125, 93-97.

Ziegler, H., Spiteller, G., 1992. Coumarins and psoralens from Sicilian lemon oil (Citrus limon (1.) Burm. f.). Flavour Fragr. J. 7, 129-139.

Zygmunt, P.M., Petersson, J., Andersson, D.A., Chuang, H., Sorgard, M., Di Marzo, V., Julius, D., Hogestatt, E.D., 1999. Vanilloid receptors on sensory nerves mediate the vasodilator action of anandamide. Nature 400, 452-457. 